\title{
Law of Municipal Home Rule in Oregon
}

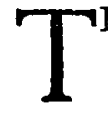

$\mathrm{HE}$ complete supremacy of state legislatures over cities is a natural corollary of the theory of our jurisprudence that sovereignty is lodged with the legislature subject only to the specific grants and limitations of the state and federal constitutions. In many states the legislatures were allowed a free hand in the field of municipal legislation, but an uneasy feeling of long standing that legislatures are too busy with other things to attend properly to their proper business (which is very nearly $\mathrm{Mr}$. Delos F. Wilcox's definition of "politics") increased in the latter decades of the 19th century to a settled conviction, greatly reenforced by the increasing civic consciousness resulting from the enormous growth of cities in population and in functions which was one of the notable developments of these years. Together they brought about widespread attempts to withdraw cities from the despotic control of legislatures and give them a measure of local independence. For the most part, these attempts followed the usual method in this country and England, that of establishing the new arrangement first, and adapting it to existing institutions and legal conceptions by means of rulings of the courts made as conflicts of rights, powers and duties arise, rather than by the elaboration of a detailed and comprehensive plan which seeks to map out with precision the extent of the new authority and its limitations. The former method, a natural offshoot of the practice of "muddling through", does seem to "set wi' the genius" of English-speaking peoples best, perhaps because we have learned better than others how hopelessly the knowledge and imagination of those who plan political institutions fall short of the infinite variety of circumstance and conduct which have to be met with and provided for in our energetic and progressive western societies. Certainly the constitutional provisions by which home rule was granted to Oregon cities did not err on the side of too sedulous concern for the details of the plan. On the contrary, they were exceedingly concise, not to say bald.

In 1902, section 1 of Article IV of the constitution of Oregon had been amended to reserve to the people the power of direct legislation-the initiative and referendum. To this article in 1906 was added a section, which contained the following clauses:

"Sec. 1a. Initiative and Referendum on Local, Special, and Municipal Laws, and Parts of Laws. The initiative and referendum powers reserved to the people by this constitution are hereby further reserved to the legal voters of every 
municipality and district, as to all local, special, and municipal legislation, of every character, in or for their respective municipalities and districts. The manner of exercising said powers shall be prescribed by general laws, except that cities and towns may provide for the manner of exercising the initiative and referendum powers as to their municipal legislation. Not more than ten per cent. of the legal voters may be required to order the referendum nor more than fifteen per cent. to propose any measure, by the initiative, in any city or town."

By the same submission, section 2 of Article XI, constitution of Oregon, which had formerly provided that corporations might be formed under general laws but should not be created by the legislature by special laws, except for municipal purposes, was amended to read as follows:

"Sec. 2. Formation of Corporations-Municipal Charters, How Enacted. Corporations may be formed under general laws, but shall not be created by the legislative assembly by special laws. The legislative assembly shall not enact, amend, or repeal any charter or act of incorporation for any municipality, city, or town. The legal voters of every city and town are hereby granted power to enact and amend their municipal charter, subject to the constitution and criminal laws of the State of Oregon."

This section was amended again in 1910 to vest in cities the exclusive power to regulate and prohibit the sale of intoxicating liquors subject to the then existing local option law, but this part of it is not material for our present purposes.

These two sections constitute the charter of Oregon's municipal liberties. Oregon towns have been very active in the use of it. Examination in 1917 of the charters of cities and towns which have been filed with the librarian of the state library, in pursuance of a statute authorizing the courts to take judicial notice of them when so filed, showed that of such towns claiming a population of five hundred or more, forty-eight had adopted complete initiative charters, forty others had amended their legislative charters by the initiative and only about a dozen had neglected entirely to avail themselves of the opportunities afforded by the constitutional amendments. ${ }^{1}$

$x$ Professor Howard Lee McBain in his valuable work on the $\mathrm{Law}$ and Practice of Municipal Home Rule, published in 1916, asserts that only five cities in Oregon have availed themselves of the constitutional right. The extreme difficulty of obtaining accurate information on the subject prior to the enactment of the statute above mentioned may excuse the error, which is a pretty large one, something like 100 cities and towns of all sizes instead of five having actually exercised the right to enact or amend their charters. The incident serves to show the uncertainty of political information obtained at a distance and the great danger of drawing inferences based on long- 
Some scores of cases affecting the interpretation and application of these sections have found their way to the Oregon Supreme Court. The principles deducible from these cases form a very important part of the municipal home rule system in Oregon and a brief study of them may not be without value elsewhere.

The chief controversy to which the exercise of home rule powers has given rise is as to the extent of the powers remaining in the legislature in respect to the "cities and towns, municipalities and districts" which are referred to in the amendments; specifically, how far these bodies can still be regulated by the legislature by general laws.

Closely related to this question and, in the litigation as it arises, difficult to distinguish from it, is the question as to what powers are conferred upon and exercisable by cities.

Of less general interest, perhaps, but not less important to the municipalities concerned, being as they are creatures of positive law whose acts and powers are subject to technical limitations, are the numerous controversies which arise respecting the machinery through which their powers are put into operation.

\section{The Powers Remaining in the Legislature.}

There has long existed in the state a class of municipalities called "ports", created to improve and deepen its harbors and to promote its shipping. These, partly because their newness had left many questions concerning their powers and rights unsettled by "use and wont", have given rise to much litigation. The ink was hardly dry on the constitutional amendments when the legislature passed an act creating the Port of Columbia, composed of three counties bordering on the Columbia River, constituting them a port corporation with power to issue bonds, levy taxes, maintain a towage and pilotage system, and so forth. The courts promptly held $^{2}$ that this act was a special law expressly prohibited by the provision above quoted of section 2, Article XI, that corporations should not be created by the legislative assembly by special laws.

At the next session, a law was passed providing for the forma- tion of ports in counties bordering on waters navigable from the sea, upon the filing of a petition with the county court calling for

range data. Some of Professor McBain's conclusions as to the law in Oregon should also be rectified in the light of decisions hereinafter cited and not referred to by him, e. g., the leading case of Straw v. Harris (1909) 54 Ore. 424, 103 Pac. 777. For fuller particulars as to the exercise of home rule powers in Oregon towns, see paper in the proceedings of the 4th Annual Convention of the Illinois Municipal League, November, 1917.

2 Farrell v. Port of Columbia (1907) 50 Ore. 169, 91 Pac. 546, 93 Pac. 254. 
a vote of the citizens of the territory included in the proposed corporation, and upon compliance with certain formalities following a favorable vote at the election. This, it was contended, was merely an attempt by the legislature to do indirectly what it could not do directly; a delegation by the legislature of its former powers to the county court-the tribunal to which the act confided the duty of calling the election, declaring the result, and so forth. The court decided, ${ }^{3}$ however, that the word "corporation" used in section 2, Article XI, was employed in the broadest sense to include both public and private corporations and therefore authorized the creation of municipal corporations (to which class ports were held to belong) by general law, and that the act in question, being one by which all persons or localities complying with its provisions are entitled to exercise the powers, rights and privileges conferred, was a general law and authorized by the amendment. This rule was followed in Bennett Trust Co. v. Sengstacken ${ }^{4}$ as to ports, and in State $r$. Bay $\mathrm{City}^{5}$ as to cities and towns. This last decision declared valid an act passed in 1893, many years before the home rule amendments were incorporated in the constitution. which had been very sparingly used, many lawyers having doubts as to its validity; and put beyond a doubt the power of the legislature to enact a general law for the incorporation of all sorts of "municipalities and districts".

This was all fairly easy and obvious, but in Straw v. Harris ${ }^{6}$ arose a much more difficult question, involving, though indirectly, the real crux of the problem. The Port of Coos Bay attempted to include within its boundaries a number of incorporated towns, in one of which a majority of the electors voted against the incorporation of the port. The statute from which the port derived its powers gave it control over wharves, docks, channel improvements and the like, which had previously been within the jurisdiction of the several included towns. It was contended thereupon that the port law in effect amended the charter of these towns, a thing which the legislature was expressly prohibited by the constitutional amendments from doing, and that it was therefore invalid. The court decided to the contrary, declaring that the power to form municipalities such as ports, irrigation and drainage districts and the like by general laws necessarily implied the power to include within them lesser municipalities, a proposition which is

${ }^{3}$ Straw v. Harris, supra, n. 1.

* (1911) 58 Ore. 333, 113 Pac. 863.

5 (1913) 65 Ore. 124, 131 Pac. 1038.

Supra, n. 1. 
at least arguable. But it went further and boldly announced the important principle, decisive in great measure, if valid, of the whole controversy under discussion here, that the constitutional amendments had not availed to impair the power of the state, or the legislature as its agent, to enact general laws affecting cities. Speaking by Mr. Justice King, the court said:

"True, the language used in the amendments considered would appear to give to incorporated cities the exclusive control and management of their own affairs, even to the extent, if desired, of legislating within their borders without limit, to the exclusion of the state. But, as stated, these provisions must be construed in connection with others of our fundamental laws, which can but lead to the conclusion above announced; and whatever may be the literal import of the amendments it cannot be held that the state has surrendered its sovereignty to the municipalities to the extent that it must be deemed to have perpetually lost control over them. This no state can do. The logical sequence of a judicial interpretation to such effect would amount to a recognition of a state's independent right of dissolution. It would but lead to sovereigntial suicide. It would result in the creation of states within the state, and eventually in the surrender of all state sovereign-all of which is expressly inhibited by article 4 , $\S 3$ of our national Constitution. Power to enact local legislation may be delegated, but this of necessity, whether stated or not, is always limited to matters consonant with, and germane to, the general purpose and object of the municipalities to which such prerogatives may be granted. Municipalities are but mere departments or agencies of the state, charged with the performance of duties for and on its behalf, and subject always to its control. The state, therefore, regardless of any declarations in its constitution to the contrary, may at any time revise, amend, or even repeal any or all of the charters within it, subject, of course, to vested rights and limitations otherwise provided by our fundamental laws. This, under the Constitution as it now stands, may be done by the Legislature through general laws only, and the same authority may be invoked by the people through the initiative by either general or special enactments; only the Legislature being inhibited from adopting the latter method."

This decision cut to the heart of the controversy and commanded wide and respectful attention. In Kiernan v. Portland ${ }^{7}$ it was further declared by the same judge that the only restriction imposed by section 2, Article XI, upon the legislature pertained to the passage of special laws affecting municipalities. He declared, 
however, that the people might by constitutional amendment reserve to themselves the right to enact any law to the exclusion of the legislature and by that method might delegate to municipalities powers not subject to abridgement, limitation, change or recall by special act of the legislature, and by the constitution the people could delegate directly to municipalities any powers which it could formerly have granted to the legislature.

In Churchill v. Grants Pass $^{8}$ the principle of Straw v. Harris was re-examined to the effect that the relation of municipal corporations to the state was not changed by the constitutional amendments, which left them as they were before, mere agencies of the state, which might by general law control them even to the extent of amending their charters. The same criterion of the validity of a charter, that it might be such as the legislature could have enacted before it was deprived of the power was offered again in State ex rel. v. Portland.

Conflict between the powers of the state and city soon arose in another field and was determined in like manner in a series of cases, several of which were tried in the United States courts. An act creating a public service commission and conferring upon it power to fix public utility rates was passed by the legislature in 1911 and ratified by the referendum in 1912. This act provided that the rates in force at the time of its passage should continue in force until changed by the commission. The town of Grants Pass attempted to change the rates chargeable under a franchise granted by it, and after they had been filed with the commission enacted an ordinance making it a misdemeanor to collect any other rates than those fixed by the city. The United States District Court for Oregon in California-Oregon Power Company v. Grants Pass $^{10}$ enjoined the city from enforcing the ordinance, holding that the state law amended city charters giving power to fix rates. The constitutional amendments were not adverted to in this case, but Portland Railway, Light \& Power Company v. Portland ${ }^{11}$ was expressly rested on the authority of Straw v. Harris. In the Portland case the city council, under authority of a charter giving the power to fix rates chargeable by public utility companies operating within the city, had attempted to require a street railway company holding a franchise at a five-cent rate to sell six tickets for twenty-five cents. The court held that the franchise rate was

- (1914) 70 Ore. 283, 141 Pac. 164.

9 (1913) 65 Ore. 273, 133 Pac. 62.

10 (1913) 203 Fed. 173.

11 (1914) 210 Fed. 667. 
not final as against the sovereign power of the state over the subject and that the' constitutional amendment did not authorize the people of a city to amend its charter so as to confer upon the municipality powers which are either beyond those purely municipal or which are inconsistent with a general law of the state constitutionally enacted. Mr. Justice Bean very cogently pointed out that the state law would be made a mere nullity if every city had and exercised the power claimed.

It may as well be said here, following this series of cases down to the present time, that in Woodburn v. Public Service Commission, ${ }^{12}$ a case in which there was a most exhaustive discussion of the subject, and in Portland v. Public Service Commission ${ }^{13}$ and the recent case of Salem v. Salem Water Company, ${ }^{14}$ circuit court of appeals, ninth circuit, these decision have been followed and extended so that it seems to be firmly settled that the powers of cities do not include that of making rates for public service companies, such power not being of a municipal or local character, and that the public service commission may change a rate fixed by a city in a franchise granted pursuant to an initiative amendment to its charter. They perhaps go even so far as to hold that the state cannot abdicate this power. In the Salem case the question of whether there can be a contractual relation between the state and city is brought into the discussion.

Meanwhile, however, and before the decisions last mentioned, the pendulum had begun to swing in the opposite direction and the court had entered upon a course of decision which irresistibly reminds one of the recommendation offered by the great Matt Carpenter in favor of the New York reports. "Buy the New York reports, buy the New York reports," he said to a young man who asked his advice as to the foundation of a law library. "Somewhere in them you will find well-considered decisions on both sides of every important question."

In Portland v. Nottingham ${ }^{15}$ the doctrine of Straw v. Harris was departed froin on a point which concerned an appeal from a judgment on a city street assessinent, the court distinguishing the instant case on the ground that the rule established by the city charter referred to a purely inunicipal matter.

In 1913 the legislature passed an act which provided a pension fund for police and firemen applying to cities having more than

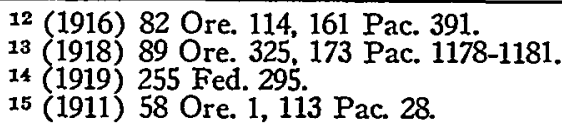

12 (1916) 82 Ore. 114, 161 Pac. 391.

13 (1918) 89 Ore. 325, 173 Pac. 1178-1181.

14 (1919) 255 Fed. 295.

15 (1911) 58 Ore. 1, 113 Pac. 28. 
fifty thousand inhabitants. There was but one such in the state and the act showed in almost every line that it was created for Portland alone. Provisions of a similar nature, though somewhat less liberal, were found in the city charter. In a proceeding to enforce this act $^{16}$ the court found that the act was an attempt by implication to amend the sections of the Portland charter, that the subject of pensions for its officers was purely city business, that the statements quoted above from Straw v. Harris were mere dicta and that the inhibition against the amendment of city charters by the legislature was absolute. It would seem that this decision might well have rested upon the basis that the act was in fact a special law, but the court very positively took the other ground. Mr. Justice McBride, who a month previously had rendered the decision in Churchill v. Grants Pass, ${ }^{17}$ naturally dissented. The point arose again in Kalich v. Knapp ${ }^{18}$ on a question as to the enforcibility of the state law regulating the speed of motor vchicles in a city which had different regulations in its ordinances. Upon much consideration and after a rehearing had been granted, the majority of the court adhered to the position taken in Branch v. Albee. This decision was followed in a case arising on the identical question in Everart v. Fisher ${ }^{19}$ and in Pearce v. Roseburg. ${ }^{20}$

In this case Mr. Justice McBride announced the view of the court that a law attempting to restrict the powers of cities and towns to levy taxes was obnoxious to the home rule amendments and remarked that as to matters purely municipal it was well settled in this state that the legislature could not intermeddle either with general or special legislation, and further that as to matters affecting the people generally this proposition could rot be maintained until the court should materially modify its holding in Kalich v. Knapp. There was thus a flat and irreconcilable contradiction between the two lines of decision which demanded resolution.

In well considered opinions in the cases of State v. Port of Astoria $^{21}$ and Rose v. Port of Portland ${ }^{22} \mathrm{Mr}$. Justice Harris, who had come to the bench since the decision in Kalich v. Knapp, undertook a thorough and minute examination of the two constitutional amendments in question, and as a result of a cogent and

${ }^{16}$ Branch v. Albee (1914) 71 Ore. 188, 142 Pac. 598.

17 Supra, n. 8.

18 (1914) 73 Ore. 558, 142 Pac. 594, 145 Pac. 22.

19 (1915) 75 Ore. 316, 145 Pac. 33, 147 Pac. 189.

20 (1915) 77 Ore. 195, 150 Pac. 855.

21 (1916) 79 Ore. 1,154 Pac. 399.

22 (1917) 82 Ore. 541, 162 Pac. 498. 
masterly analysis of their text, reinforced by considerations of the history of the amendments and of the arguments urged upon their adoption, of their practical construction since, and the inconveniences and injustice which would result from any other interpretation, arrived at conclusions which he stated as follows:

"The legislative assembly cannot create any corporation by a special law; but corporations of all kinds may be formed under appropriate general laws passed by the legislative assembly. Charters or laws granting or enumerating the powers exercisable by a corporation are indispensable. Cities and towns can enact or amend their own charters, but no other corporate body can, without an enabling act, legislate power unto itself to legislate. The legislative assembly cannot enact a special measure which enacts, amends or repeals a specified city or town charter or act of incorporation of a municipality, other than a city or town. The legislative assembly can enact a general law affecting the charters or acts of incorporation of all cities or towns, or municipalities or districts. If a municipality has within itself a representative law-making body then the legal voters of such municipality can apply the referendum to any measure passed by that representative body; if the legislative assembly passes a special measure for a specified municipality or district, other than a city or town, then the legal voters of that municipality can apply the referendum to that special measure for the reason that this gives practical application to article IV, section 1a, which reserves the referendum 'as to all local, special and municipal legislation of every character in or for their respective municipalities,' and also carries into execution the purpose expressed in the argument submitted by the framers of the amendment to the constitution. The people of the state at large can apply the referendum to all general municipal legislation, but the legal voters of an individual municipality cannot refer to themselves, as distinguished from the voters of the state at large, any general municipal measure passed by the legislative assembly."

The decision in these cases completely overrules Kalich v. Knapp and its supporting authorities, but curiously enough that case is not even mentioned in the thirty-five pages given to Rose v. Port of Portland in the Oregon reports. Moreover, neither of the last two cases involves cities and towns and the law in regard to ports is clearly and pointedly distinguished from that affecting cities and town in Mr. Justice Harris' decision. Notwithstanding, however, that these opinions are subject to criticism as dicta, the complete and thorough character of the interpretation put upon the constitutional clauses in these opinions, together with the obvious propriety and convenience of the rule announced, warrant 
us in believing that the question is finally settled in its broad outlines.

It is interesting to note that the overruled cases are rested largely upon the proposition that there is a field of purely municipal legislation within which the cities are supreme and that the later and prevailing decisions abandon or at any rate pass over this theory. In practice, the theory is found not to work well. For example, there could hardly be a subject which at first blush would seem more exclusively within the field of municipal legislation than the regulation of the speed of vehicles in the streets, and such was the view of the court in Kalich v. Knapp, yet this proposition leads to intolerable absurdities and inconveniences in practice, since it exposes the traveling motorist to regulations differing in every village and hamlet through which he passes and compels him either to submit to amercements, sometimes grievous and unjust, or else to undertake the impossible task of acquiring a complete code of conduct for every such village. The solution of the problem goes back to the proposition stated at the outset of this article, namely, that municipalities are creatures of the state without any autonomous rights, and it seems probable that this proposition is sound in law, at any rate for states where formal organization of municipalities did not antedate the Constitution, as it did in some of the original thirteen states. The question has been raised anew in the Supreme Court of Oregon in a case now pending therein and not yet argued; Lovejoy v. City of Portland, wherein the learned city attorney contends that cities have certain independent and autonomous rights and powers, upon which the state cannot encroach even by general legislation, citing to the point, amongst other authorities, a series of articles by Amasa $M$. Eaton in the Harvard Law Review. ${ }^{23}$ It seems to be admitted on all hands that the people of the state at large, acting through the initiative, may enact general laws. which have the effect of amending the charters of cities.

Since the case of Rose v. Port of Portland, ${ }^{24}$ it has been held in State ex rel. v. Mehaffey ${ }^{25}$ that the legislature may amend the charters of existing drainage districts, which, of course, come within the class of municipalities other than cities and towns, and in Colby v. Medford ${ }^{26}$ it has been held that a state statute, known as the Bancroft Bonding Act, first enacted in 1901, which provides

2313 Harvard Law Review, 441, and subsequent issues.

24 Supra, n. 22.

25 (1917) 82 Ore. 683, 162 Pac. 1068.

26 (1917) 85 Ore. 485, 167 Pac. 487. 
a method by which cities may collect assessments for street improvements by installments, applies to and becomes a part of the charter of every city in the state and that no city may by its charter or other provisions violate the act, although cities may provide supplementary and alternative methods to secure the same result. This matter also would seem to fall within the field of exclusively municipal legislation, if anything could.

II. Extent of Municipal Powers.

The municipal activities most likely to be promptly challenged are such as are exercised without the boundaries of the city, and the frequent occasion for such activities in condemning land for water supply, park purposes, annexation of territory and the like became at an early time the subject of judicial inquiry.

In McMinnville v. Howenstine ${ }^{2 \tau}$ it was decided that a city had power to condemn a right of way for a pipe line without its boundaries. The opinion placed the decision upon the ground of the city's general rights of legislation, but was subsequently disapproved in this respect, although the judgment was upheld because there existed a state statute conferring on cities the right to condemn for such purposes. In Thurber v. McMinnville ${ }^{28}$ it was decided that a municipality, in the absence of express legislative power (general as to all cities of a like class) has neither power to condemn land without its boundaries nor any other extra-territorial power whatever.

Riggs v. Grants Pass $^{29}$ laid down the rule that a city cannot amend its charter by the initiative so as to confer upon itself power beyond what is properly inunicipal, or local, and therefore a charter amendment attempting to authorize the issuance of bonds for the building of a railroad without the city was void. A subsequent charter amendment, adopted after an enabling act was passed by the legislature, was held valid, and the authority of the legislature to delegate to a municipality power of this character, which was found by the court to be public and municipal, was upheld. ${ }^{30}$

It has been the practice of the legislature in enacting city charters to grant to the city the right to turn into its treasury the road taxes collected under the general road laws within the city limits, and to confer upon the cities jurisdiction over county roads

\footnotetext{
27 (1910) 56 Ore. 451,109 Pac. 81.

28 (1912) 63 Ore. 410,128 Pac. 43.

29 (1913) 66 Ore 266, 134 Pac. 776.

30 Churchill v. Grants Pass, supra, n. 8.
} 
lying within their boundaries. In West Linn $\mathrm{v}$. Tufts, ${ }^{31}$ the first of these, and in Cole v. Seaside ${ }^{32}$ and Christie v. Bandon, ${ }^{33}$ the latter, was held beyond the power of a "self-constituted" city; that is to say, a city which derives its power from the vote of its citizens and not from a direct grant by the state legislature. In the latter two cases the opinion adverts to the fact that the right of cities to legislate is by the constitution made subject to the criminal laws of the state and that the general law conferring authority upon the county courts over county roads is enforced by penal provisions.

In the decisions by Mr. Justice Harris hereinbefore referred to, ${ }^{34}$ he classifies the powers which a city may exercise, "for want of a better term", as intramural and extramural, and lays down the rule in this language:

"The legal voters of cities and towns may exercise the whole sum of intramural powers or such parts thereof as they desire, subject to the constitution and criminal laws of the state, and subject to the right of the people of the entire state to act under the initiative, but they can exercise extramural legislation only when the right to exercise it has been granted by a general law passed by the legislature or the people of the state."

The distinction is one which has yet to be mapped out in detail on the ground, so to speak, but most cases will readily be seen to fall into one class or the other without question. Marginal instances there must be which perplex and make difficult the application of every rule.

\section{Annexation and Consolidation.}

The prevalent desire to have everything as big as possible, leads, especially in regions where growth is rapid, to continual attempts on the part of ambitious towns to widen the borders of their garments by annexation of adjoining territory and by consolidation with neighboring municipalities. The power of the legislature to annex territory to a town or to incorporate it with another one was regarded as plenary prior to the conferring of the home rule powers upon cities. ${ }^{35}$

The legislature in 1893, long before the home rule amendments were enacted, had adopted a general law providing methods for

31 (1915) 75 Ore. 304, 146 Pac. 986.

32 (1916) 80 Ore. 73, 156 Pac. 569.

33 (1917) 82 Ore. 481, 162 Pac. 248.

34 State v. Astoria, supra, n. 21 ; Rose v. Portland, supra, n. 22.

35 Winters v. George (1891) 21 Ore. 251, 27 Pac. 1041. 
both annexation of unorganized territory and consolidation of organized municipalities.

In McBee v. Springfield ${ }^{36}$ this statute was held valid as to unorganized territory. In McKeon v. Portland ${ }^{37}$ an attempted consolidation of the suburban town of St. Johns with the city of Portland, where no corporate action had been taken by the annexed town, although the electors therein had voted for the annexation in pursuance of ordinances of the city of Portland, was set aside. The opinion took the position that the constitutional amendments made no provision for the extension of a city's franchise by such, or indeed by any, means, and that it would be municipal suicide; "led like a lamb to the slaughter and opening not its mouth" perhaps. This led to the adoption subsequently of a constitutional amendment adding to Article XI, following section 2 , a section $2 a$, which provided that the legislative assembly or the people by the initiative might enact a general law providing a method whereby an incorporated city, town or municipal corporation might surrender its charter and be merged in an adjoining city or town, the electors of each city to vote favorably thereon.

In State on inf. v. Gilbert, ${ }^{38}$ however, the court receded from the position taken in the McKeon case and declared the statute for the consolidation of neighboring towns valid, distinguishing the McKeon case on the ground of the want of corporate action on the part of the smaller municipality. The constitutional provision had, meanwhile, set the whole question at rest, and this somewhat tenuous distinction will not have to bear any subsequent strains.

The right of the territory annexed to vote on the question has been rather jealously guarded by the courts. Annexations have been invalidated for want of it in several cases. ${ }^{39}$ The converse of this proposition, namely, that a city may by its own act exclude territory from its limits, is asserted in Flavel Company v. Leinenweber. ${ }^{40}$ A peculiar modification of this rule was

${ }^{36}$ (1911) 58 Ore. 459, 114 Pac. 637.

37 (1912) 61 Ore. 385, 122 Pac. 291.

38 (1913) 66 Ore. 434, 134 Pac. 1038.

39 State ex rel. v. Port of Tillamook (1912) 62 Ore. 332, 124 Pac. 637; Thurber v. McMinnville (1912) 63 Ore. 410, 128 Pac. 43; Landess v. Cottage Grove (1913) 64 Ore. 155,129 Pac. 537, where a vote taken promiscuously in the city and the annexed territory was held insufficient; Couch v. Marvin (1913) 67 Ore. $341,136 \mathrm{Pac}$. 6, where there were but two persons resident in the annexed territory for which no election was provided; Cook v. Portland (1914) 69 Ore. 572, 139 Pac. 1095, where the method provided by the Portland charter of 1893 was held bad, among other reasons, for want of proper provisions for separate vote.

10 (1916) 81 Ore. 353, 158 Pac. 945. 
declared in State on inf. v. Johnson, ${ }^{41}$ where it was held that a port might by its constitution acquire jurisdiction over territory included within the boundaries of another port created primarily to improve other waters. This decision rests partly upon the peculiar nature of the "port" municipalities, partly upon grounds expressed in State v. Hall,"2 holding that a union high school district might be created to embrace a number of school districts, and partly upon the general doctrine promulgated in Straw v. Harris, ${ }^{43}$ which recognizes the priority of the general authority of the state over its municipalities.

Other questions respecting the powers of municipalities under the amendments have been answered by the courts. Thus the power of a city to impose the care of bridges upon the county was denied in Kiernan v. Portland.44 The right of a city to prescribe in its elections the use of the preferential ballot (permitted by the constitution) and to prohibit the designation of political parties on the ballot was upheld in State ex rel. v. Portland. ${ }^{45}$ The right of cities, however, to impose limitations on the franchise other than those prescribed by the general law of the state was denied in State ex rel. v. Dalles City ${ }^{46}$ and in Pearce v. Roseburg." The right of a port commission to buy and sell coal to ships was upheld in Stevenson v. Port of Portland ${ }^{4 s}$ (contrary to the established rule in Massachusetts), and the power to regnlate the maintenance of a millrace along a street in a town was declared to be within the constitutional powers of cities in Gaston v. Thompson. ${ }^{48}$

\section{The Machinery.}

The means of putting the constitutional powers into effect and of the application of the constitutional amendments have given rise to some difficulties. It seems sufficiently obvious, in view of the authority to enact and amend their own charters granted by the constitution to cities and towns, that "the initiative and referendum powers as to municipal legislation" granted by another section of the constitution would apply to their organic acts, but

11 (1914) 76 Ore. 85, 144 Pac. 1148, 147 Pac. 926.

42 (1914) 73 Ore. 231, 144 Paç. 475.

43 Supra, n. 1.

14 Supra, n. 7.

45 (1913) 65 Ore. 273, 133 Pac. 62

46 (1914) 72 Ore. 337, 143 Pac. 1127.

47 (1915) 77 Ore. 195, 150 Pac. 855.

18.(1917) 82 Ore. 576.162 Pac. 509.

19 (1918) 89 Ore. 412,174 Pac. 717. 
a decision of the supreme court seems to have been required to establish that rule. ${ }^{\text {so }}$

Less obvious is the answer as to whether, under the constitutional provisions, municipalities other than cities and towns can amend their charters by the initiative, and accordingly we find that the first decision allowing this right to "ports" in State v. Port of Astoria, s2 which holds that no municipalities other than cities and towns can legislate any power unto themselves without the aid of a statute passed either by the legislature or the people of the whole state. This case points out further that cities and towns have, beside the privilege of defining their own authority, that of prescribing their own procedure for the exercise of the initiative and referendum.

The quotation from Rose v. Port of Portland ${ }^{53}$ sets out pretty fully the present view of the court as to the exercise of these powers. Counties are held to be "municipalities or districts" within the purview of the home rule amendments and may exercise initiative powers. ${ }^{54}$ They cannot, however, initiate a law unless the power to enact it is referable to a grant from the people of the state directly or through the legislature. ${ }^{55}$ This last decision should have endeared the court to the jack-rabbit population, the death rate among which would have been much increased by the bounty which had been voted by the county.

Of the remaining determinations of the courts in this field, it is perhaps enough to say that they have been marked by an intelligent regard for the purposes sought to be obtained and by a firm and constant intention not to allow the multitude of trivial errors and irregularities which inevitably creep into this sort of proceedings to invalidate the result; an application throughout of the principle that the election "is the vitalizing act, all going before being mere formality and preparation." ${ }^{\text {"se }}$ They have, however, insisted strictly upon compliance with those parts of the law which

30 Acme Dairy Co. v. Astoria (1907) 49 Ore. 520, 90 Pac. 153.

51 Farrel v. Port of Portland (1908) 52 Ore. 582, 98 Pac. 145.

52 (1916) 79 Ore. 1, 154 Pac. 399.

63 Supra, n. 22.

54 Schubel v. Olcott (1912) 60 Ore. 503, 120 Pac. 375; Barber v. Johnson (1917) 86 Ore. 390, 167 Pac. 800. 1183.

os Schubel v. Olcott, supra, n. 54; Carriker v. Lake County (1918) 89 Ore. 240, 171 Pac. 407, 173 Pac. 573.

so Colby v. Medford (1917) 85 Ore. 485,167 Pac. 487. 
require notice to the electors of the subject matter and time and place of the election. Some details are given in the foot-note. ${ }^{57}$

Summing up, we find that after a good deal of vacillation, the Oregon courts have planted themselves pretty firmly in the position that the right of cities and towns to make their own organic laws, and thereby define the extent of their own powers, is conferred upon them by the constitution, subject to the superior authority of

s7 There was a good deal of rather futile discussion as to whether the constitutional provisions were "self-executing"; that is to say, whether they went into operation without legislation or required it. Acme Dairy Co. v. Astoria (1907) 49 Ore. 520, 90 Pac. 153; Long v. Portland (1909) 53 Ore. 92, 98 Pac. 149, 98 Pac. 1111 ; State ex rel. v. P. R. L. \& P. Co. (1910) 56 Ore. 32, 107 Pac. 958; Kiernan v. Portland, supra, n. 7; Schubel v. Olcott, supra, n. 54. Duncan v. Dryer (1914) 71 Ore. 548, 143 Pac. 644 and Pearce v. Roseburg (1915) 77 Ore. 195, 150 Pac. 855, hold that cities have power to provide by ordinance the method of adopting new charters by the initiative. State v. Andresen (1915) 75 Ore. 509, 147 Pac. 526, declares that omission on the ballot of the words "charter amendments submitted by council" does not invalidate an election for the adoption of such amendments. Birnie v. LaGrande (1915) 78 Ore. 531, 153 Pac. 415, holds that enactment by the council of a proposed charter does not put it in effect, but merely expresses the assent of the council, which is only provisional until it is favorably acted on by the voters. It is required, however, that the council formally pass a measure to be submitted and the failure to do so invalidates the submission. Thielke v. Albee (1915) 76 Ore. 449, 150 Pac. 854. Thielke v. Albee (1916) 79 Ore. 48, $153 \mathrm{Pac}$. 793, holds that cities have power to pass an ordinance which shall take effect at once under an emergency clause. Colby v. Medford (1917) 85 Ore. 485, 167 Pac. 487, holds that omission of an enacting clause does not affect the validity of an amendment when the ordinance requiring such a clause in effect at the time the amendment was filed is repealed before the election at which it is submitted to the voters, and that the constitutional provision providing the style of all bills and requiring an enacting clause does not apply to charter amendments. See also State ex rel. v. Dalles City (1914) 72 Ore. 337, 143 Pac. 1127. Curtis v. Tillamook (1918) 88 Ore. 443, 171 Pac. 574, holds an election for the adoption of a charter amendment valid when it was held under the method prescribed by an ordinance which went into effect after the charter amendment was ordained and referred by the council, but before the election was held. Haines v. Forest Grove (1909) 54 Ore. 443, 103 Pac. 775, holds that only a majority of those voting on an amendment is necessary to pass it. An amendment proposed and submitted to the yoters of the state to change this rule and require in direct legislation elections generally a majority of the electors, or of all of the votes cast at the election, failed signally. That cities have the power to repeal objectionable sections without enacting others in their stead, notwithstanding the power to repeal is not expressly given, and that numerous amendments creating a commission form of government may be submitted together, and that parts of a former charter may be continued in a new one as ordinances only and therefore subject to repeal by the council, is ruled in State ex rel. v. Portland (1913) 65 Ore. 273, 133 Pac. 62. On the other hand, failure to include in the printed copy of a measure required by the ordinance to be printed and mailed to all voters the name of one of the commissioners chosen by the measure was held fatal to the election in Palmberg v. Astoria (1912) 63 Ore. 222, $127 \mathrm{Pac}$. 32. So also a failure to publish or post the measure in the manner required by the submitting ordinance. Wright v. McMinnville (1911) 59 Ore. 397, 117 Pac. 298; State ex rel. v. Dalles City, supra; Provoost v. Cone (1917) 83 Ore. 522, 162 Pac. 1059, 1060. 
the state, whenever that authority is exercised by a general act of the legislature applying to all cities which fall within its scope, or by enactment of the people under the initiative. In the matter of making public utility rates, the predominance of state authority is especially well settled. The distinction between subjects which are of general and those which are of exclusively local and municipal concern has not been maintained so as to mark off a field within which municipal powers are definitely and at all events superior to or independent of those of the state. A like distinction is maintained at a step further down, however; that is to say, powers which are properly municipal may be exercised by cities unless they run counter to an act of the state, while powers which are not strictly municipal, but extramural, in Mr. Justice Harris' words, such as building railroads or condemning lands without their boundaries, can be exercised only when the formal consent of the state is given. The very generous disposition shown by the legislature toward cities has found expression in the granting by general laws of powers to do almost anything which the most enterprising and adventurous city would be likely to undertake, and the question thus becomes of minor practical inportance. One power which is necessarily extra-territorial, the annexation of adjacent territory, cities may exercise, just as they may create themselves from unorganized territory, and here the courts have guarded with jealous and meticulous care the right of the occupants of this territory to vote on the question in the precise manner and form prescribed, whether the vote could make any difference in the result or not. Municipalities other than cities and public corporations, like counties (which are less than municipalities) may only exercise the powers of popular legislation pursuant to an enabling act-as in the case of extra-territorial activities by cities and towns.

The courts have shown a wise desire to disregard minor and unimportant irregularities and inaccuracies in the enactment of municipal legislation through the initiative, where the question at issue has been fairly put before the electorate and favorably voted upon. They have, however, insisted pretty strictly on compliance with all provisions for notice, both of the holding of the election and of the terms of the matters submitted-as part of the "due process" for which the law of this land has an immemorial concern.

When we remember that under the Oregon constitution cities were not merely permitted but compelled to make and amend 
their own charters and that the courts were in that matter launched on an almost uncharted sea, it is perhaps not too much to say that they have found their bearings very well and have mapped out a system, not complete and not perfect, but on the whole rational and conducive to just, orderly and efficient conduct of the affairs within its scope, which is the chief end of law, if not the chief end of man.

Portland, Oregon.

Richard W. Montague. 